\title{
The Border of Responsibilities in Global Distribution of Aid: Ethical Issues and Challenges in Practices
}

\author{
Mutiara Pertiwi \\ UIN Syarif Hidayatullah Jakarta
}

\begin{abstract}
This essay intends to analyse the debate about responsibility in the discourse of global justice. The topic is inspired by the statement of Thomas Pogge who argues that the minor outcome in promoting global justice is generated by a deep ethical problem on the question of responsibility rather than a technical problem such as taxation and liberalisation policy (2001a). He argues that many global problems would be solved if only the affluent countries perceived their roles in sending foreign aid as a responsibility and not as charity, which is how many communitarians perceive it. This ethical debate will be the concern of my essay. The main agenda is to find the most convincing argument for ethical guidance in the current world. Analysing through the lenses of Bertrand Russell's (1961) parameter of 'commendable ethics,' this essay validates Pogge's position that foreign aid from affluent states is part of negative responsibility and therefore commendable as an ethical guide in promoting globaljustice.
\end{abstract}

Keywords: global justice, international aid, ethics, negative responsibility.

Esai ini bertujuan untuk mengkaji perdebatan tentang kewajiban negara dalam wacana keadilan di level global. Pemilihan topik tersebit terinspirasi dari pernyataan Thomas Pogge bahwa sulitnya pencapaian keadilan global bukan semata karena kegagalan hal-hal teknis seperti kebijakan perpajakan maupun liberalisasi, melainkan lebih disebabkan oleh kesalahpahaman di level yang lebih fundamental terkait kewajiban negara. Menurut Pogge, banyak sekali masalah global yang akan selesai jika negara-negara maju meyakini bahwa pengiriman dana bantuan internasional ke negara-negara yang membutuhkan bukanlah bentuk kemurah-hatian melainkan sebuah kewajiban. Argumen ini divalidasi oleh analisis esai ini dengan menggunakan parameter 'etika terpuji' dari Bertrand Russell (1961). Sebagaimana Pogge, esai ini berpendapat bahwa bantuan luar negeri dari yang kaya kepada yang membutuhkan merupakan bagian dari kewajiban negatif semua negara. Etika ini yang seharusnya terinternalisasi dalam semua upaya menuju dunia yang lebih adil.

Kata-kata kunci: keadilan global, bantuan internasional, etika, kewajiban negatif. 
Different approaches try to identify the underlying problems in promoting global justice. Some scholars contend that the commitment to promote global justice is broadly accepted in the world, so it is not an ethical debate anymore to help a distant stranger. These scholars tend to argue that the minor outcome of the current global justice agenda is driven by the lack of procedure and institutions to promote justice in a global scope. This is why Pogge (2001a) argues that the focus of global justice should concentrate more on its 'implementation', rather than a philosophical debate. Similar argument also found in Kuper (2002a, 111) which is proposing industries and market practices as more effective means to help poor people than charities. In another article, Kuper (2002b, 125) also commends Amartya Sen for proposing institutional reform as the key success of poverty eradication. Another critique to 'aid' is argued by P.T. Bauer that 'aid is said to have encouraged anti-market...which hampers growth...so resources are wasted' (cited in McCarthy, 1998). This essay intends to take part in one aspect of the above debate about responsibility in the discourse of global justice. The focus of scrutiny is the statement of Thomas Pogge who argues that the minor outcome in promoting global justice is generated by a deep ethical problem on the question of responsibility rather than a technical problem such as taxation and liberalisation policy (2001a). He argues that many global problems would be solved if only the affluent countries perceived their roles in sending foreign aid as a responsibility and not as charity, which is how many communitarians perceive it. This ethical debate will be the concern of my essay. The main agenda is to find the most convincing argument for ethical guidance in the current world.

This essay contends with Pogge's argument, that foreign aid from affluent states is part of negative responsibility and is commendable as an ethical guide in promoting global justice. To arrive at this conclusion, my essay will firstly discuss the status of the global justice discourse in international relations to reveal that the current international system is unsupportive for ethical discourses. Secondly, it will discuss disagreement about responsibility in the discourse of global justice by revealing the demands of a wider scope of justice. Finally, it evaluates the debate on responsibility and deciding which ethical choice is a better guide for the current world. Bertrand Russell's (1961) parameter of 'commendable ethics' will be utilised in analysis. These are: consistency with an agreed 'moral code', 'sincere good intention,' and the possibility to 'have good effect'. Accordingly, Pogge's argument to change the perception of affluent countries' foreign aid from 'charity' to 'responsibility' is ethically reasonable and commendable because, it is consistent with the Universal Declaration of Human Rights; secondly, it is intended to give concession to those who have been treated unfairly by the powerful; Finally, it has the possibility to promote a more just world. If only the world adopted this approach of responsibility in global justice, the effort to alleviate global sufferings could be done more effectively.

\section{The Status of Global Justice Discourse in International Relations}

The demand for global justice has increased in the post-Cold War when more actors became aware that states as the main actors in world politics do not always fulfil their roles as the primary agent of justice (O'Neil 2001, 181). As explicated in O'Neil, the primary agents of justice are actors who own 'capacities to determine how principle of justice are to be institutionalized within a certain domain.' States' limitation to take part in this role is either because of corruption, or because the state is too weak to meet its obligation in delivering the basic needs of its people (O'Neil 2001, 190). Many states were divided by civil war, while some states were politically stable but the people within them suffered oppression or poverty. The increasing concern with global warming, global disease and human trafficking are also questioning states' ability to 
respond to the negative impact of globalization properly. If one secure state does not necessarily mean secure individuals within it, then what can we do to help people who suffer in other states? This question challenges the state-centric scope of justice which operates in the current world.

There is no simple way, yet, to define global justice because scholars are still at the infant stage of understanding the discourse (Beitz 2005, 12). This terminology is mainly promoted by cosmopolitanism, but scholars within this tradition are also quite divided in many ways. Generally, global justice defenders argue that since we live in an increasingly integrated and complex world, the framework of distribution of resources should be re-evaluated in order to not harm the least fortunate actors in the system and/or to enable the effectiveness of mitigating 'global harm', not only across borders but also across time (Pogge 2005, 1). It means that there should be a broader scope of justice for not only concern about the quality of lives of our own selves or community, but also of distant strangers.

While not all poverty is a violation of human rights, most of the poverty occurring today is a result of violation of human rights (Pogge 2007, 11). Many global justice scholars refer to the huge social economic gap between the world's haves and have nots as evidence that we live in an unjust international system (e.g. Pogge 2001a; Holder 2012; Cimadamore, et al. 2016). In 2005, there were 44 percent (2,735 million people) of the world's population living below the poverty line and consuming only 1.3 percent of the global product, while high-income countries with 955 million citizens enjoy 81 percent of the global product (Pogge 2005, 1). By now, as released in the latest Oxfam Report (2018), "eighty two percent of the wealth generated last year went to the richest one percent of the global population, while the 3.7 billion people who make up the poorest half of the world saw no increase in their wealth." As argued in Hickel (2017), this "global inequality has tripled since 1960." The numbers reveal the irony that while one part of the world is 'spectacularly rich,' the other is 'distressingly impoverished' (Sen 2006, 145). This is a serious problem because poverty is by far the greatest source of human misery today. It contributes to one third (18 million people) of all human deaths annually (Sen 2006, 120). To neglect this problem, while rich states actually have ability to solve it, demonstrates inhumanity.

It is challenging to disseminate this ethical concern in an anarchical society where states are the most important actors and they are concerned only with their own interests. The term "anarchical society" here is taken from Bull (1977), refers to the modern international system which is organized under the principle of equality amongst sovereign states. In this political context, the most effective way to gain states' support on global justice agenda is by revealing the negative consequences if states do otherwise. For example, states support poverty eradication in poor countries after many findings reveal that it could breed instability in the long term (Sen 2006, 145). Many international institutions who address the global justice agenda, such as global warming, also emerge because states want to share burdens and communication in dealing with their environmental problems. When states find an agenda that 'mutually benefits,' they will allocate resources for it, and vice versa (Goodin 1988, 685). To clarify, the concept of the 'mutual benefit model' is utilized by Robert E. Goodin to explain an ethical standpoint where 'transfers across international boundaries are permissible only if they constitute mutually beneficial exchanges. The domination of this principle has made it seriously difficult for any agencies to expand justice to a country where rich states have low interests in it. For example, 'the Organization for Economic Cooperation and Development (OECD) in 1998 allocated only 21 percent Official Development Assistance (ODA) to the forty-three least developed countries and only 8.3 percent is spent on meeting basic needs' (as quoted in Pogge 2001b, 9). This allocation of funds has been governed by political considerations rather than 
ethical principles. As Nagel $(2005,118)$ exclaimed, in anarchy, justice can only be a side issue.

\section{The Disagreement on Responsibility in Global Justice}

The challenge to global justice above is a product of state-centric ethics which mainly departs from the argument of either Hobbesian social contract or Rawlsian distributive justice (Nagel 2005, 115). The former argues that “actual justice can't be achieved except within a sovereign state" while the latter argues that "the liberal requirements of justice include a strong component of equality among citizens which applies to the basic structure of a unified nation-state." Within a state-centric ethical standpoint, states do not have an obligation to help strangers because they belong to a different society (Dower in Singer (ed.) 1993, 23). Hobbesian states are the most unfriendly to global justice for perceiving it as 'a chimera' while Rawlsian states still consider transnational justice, but only if the donors' societies approve it (Nagel 2005, 115).

Commonly, the contemporary nationalist or communitarian ethics are closer to Rawlsian. They open some redistribution channels from rich countries to poorest people in other parts of the world, but it is more as charity than obligation in the framework of transnational or international justice. Nationalists commonly argue that sending foreign aid is a benevolent gesture but "charity should begin at home" (Dower in Singer (ed.) 1993, 23). This argument is driven by cost effectiveness that it is better to alleviate lesser evil in our own society than 'greater evil elsewhere.' A community has 'a special duty' to prioritize its fellow countrymen (Goodin 1988, 663) because "the state in determining what use shall be made of its own money, may legitimately consult the welfare of its own citizens rather than that of aliens" (Shue 1980 in Goodin 1988, 667). Since the world does not have a global community yet, it is 'unrealistic' to operate global justice in the same principle of 'distributive justice' at a national level (Miller 1988, 661).

Although this is the way the world operates, Thomas Pogge, one cosmopolitan scholar, refuses to take it for granted. He argues that there is a deep mistake in people's way of understanding foreign aid as charity, which should be reconsidered. He argues that all human beings were bound by positive and negative duties. The former is quite similar to communitarian's charity argument, but in cosmopolitanism charity is framed as a positive duty. This suggests that if the affluent have the ability to improve the circumstances of the poor without seriously harming themselves, the affluent have a moral responsibility to help (Pogge in Crocker and Linden 1998, 502). While this obligation suggests a duty for charity as part of humanity, the motivation is not strong enough to encourage affluent people to make sure that their ordinary transactions cause no severe deprivation to poor countries (Pogge in Pogge 2007, 17). For Pogge, this approach is not enough to frame the real 'moral connection' among people in the current world. Not only because 'positive duty' depends too much on altruism, which can't be expected to be consistent and will be on the lowest priority of affluent' states agenda, but also because it ignores the fact that the way the world operates is unjust.

On the other hand, negative responsibility demands that all human beings should do no harm to one another. Once we commit harm, we should compensate the cost and also ensure that the victims are fully compensated (Pogge in Pogge 2007, 17). To Pogge, this should be the motivation to assist distant strangers in the current international system because affluent countries have produced harm, by at least participating in the process which produced harm for the current poor people (Pogge in Crocker and Linden 1998, 502; Pogge 2007, 137). This obligation is even bigger because the developed world also 
gains profit from this process of harming others (Pogge 2001b, 14). To support this argument, he suggests at least three moral connections between the world's haves and the world's have-nots, as explained below.

First, the world we live in today was shaped by the imperial history of invasion and oppression with unbearable grievances such as 'genocide, colonialism and slavery' (Pogge 2001b, 14). Local resources were seized and surviving traditions were destroyed so the victims in this process struggled to find ways to survive for generations, and lived in deprivation (Shiva 2000). When global markets expand, these people were already disadvantaged by their starting position (Pogge in Crocker and Linden 1998, 509). The rich and the poor sides of the world are part of this history.

Second, all human beings depend on a single natural resource base, but most of them do not get a fair share when the developed world and elites of the developing world divide these goods (Pogge 2001b, 14). For example, farmers in poor countries get a very small share from the profit of the crops they have grown, while most of the profit goes to big sellers, locally and internationally, and also political elites. Pogge argues that rich countries and elites of developing countries manage these resources without leaving enough and as good for the remaining majority of humankind. Pogge equates this with murdering through economic means.

Third, all of us, including strangers on earth, currently live under the same global structure where capitalism maintains a widening global economic inequality (Pogge 2001b, 14). The current system is extremely profitable for the richest while, on the other hand, extremely coercive for the weakest. Millions of people currently live in radical poverty with no ability to escape the vicious cycle. Pogge (in Crocker and Linden 1998, 502) refers radical inequality to: (1) the poorest suffers in 'absolute term; (2) the poorest suffers than many others; (3) the suffering of the poorest is very bad and impossible to be experienced or imagined by the richest; (4) the suffering includes all aspects of their lives; (5) the suffering is actually avoidable if the richest have the will to alleviate without 'becoming badly off themselves'. This extreme situation is not only generated by government's failure in managing resources, but also because of the blindness of the global market in transferring the concession of the use of resources to unlawful or incompetent parties which puts people, as the main stake holders, aside from the optimal benefit of global transactions. This means that companies, which mainly distribute profit in developed countries, were actually taking profit from oppression in other countries. Ignoring this by defending and continuing the unjust operation of the current international order is a violation of human rights.

The explanation above reveals that the welfare in rich countries occurred largely because their unjust economic political practice in the past or present might also harm future generations. For this, affluent countries have a responsibility to fix the problem and restore a more just order. It does not mean that affluent countries should be responsible for all deprivation in the world, but primarily to those who are victims of unfair international system, which might be the majority of poorest people today.

If we observe the debate above, communitarian scope of justice is narrower than cosmopolitan. Communitarian prioritizes its community before others and encourages charity either as altruism or as a means to gain national interest. This reason might be acceptable in the context of the exclusive world, where every community is completely self-sufficient. However, this ethical standpoint becomes highly debatable in the context of globalization where almost everything is interconnected and the nature of social bond is changing over time (Higgott 2000, 131). Within this context, the good intention of the fair distribution of welfare should focus on all parties who are substantially, rather than formally, involved in the transaction. Without promoting 
this, the communitarian scope of justice is not as commended as the cosmopolitan scope of justice. At this point, it can be argued that an extreme communitarian approach is inadequate as an ethical guide to promote global justice because of its narrow scope of justice. It means that the current world needs cosmopolitan ethics as a moral code in the relationship between the affluent and the poor. The next question is which course of justice is more commendable as an ethical guide in world politics: negative or positive responsibilities. This will be answered in the following section.

\section{Revisiting the Disagreement on Responsibility}

Discussing ethics, which are inevitably concerned with what is good or bad, requires both sensitivity to context and intellectual analysis (Russell 1961). The combination of both is an effort to 'escape from subjectivity' in demanding or legitimizing what values we should pursue in our lives. Referring to Russell (1961), there are at least three different senses for which an act may be ethically commendable: (1) it is consistent with an agreed moral code; (2) it may be sincerely intended to have good effects; and (3) it may in fact have good effects. These three parameters will be my consideration in revisiting the disagreement of responsibility in global justice discourse.

The first parameter is the consistency within the existing 'moral code.' The 'moral code' that can be used here is the Universal Declaration of Human Rights (UDHR) whose scope is across community and emphasizes individuals. Hurst Hannum (in Morsink 1999, xi) finds that the UDHR has been the foundation of much of the post 1945 codification of human rights, and the international legal system is replete with global and regional treaties based, in large measure, on the Declaration. This means that the UDHR is widely accepted as ethics in international relations and violation of this could legitimize international sanctions.

As stated in the UDHR:

Article 25(1):

Everyone has the right to a standard of living adequate for the health and well-being of himself and of his family, including food, clothing, housing and medical care and necessary social services, and the right to security in the event of unemployment, sickness, disability, widowhood, old age or other lack of livelihood in circumstances beyond his control. (2) Motherhood and childhood are entitled to special care and assistance. All children, whether born in or out of wedlock, shall enjoy the same social protection;

Article 28:

Everyone is entitled to a social and international order in which the rights and freedoms set forth in this Declaration can be fully realized.

If we revisit the debate of responsibility in global justice by utilizing the above human rights framework, both positive and negative duty actually conforms to the moral code. However, their degree of conformity is different. Positive duty has a lower conformity to UDHR because it perceived that foreign aid is based on altruism while it should be perceived as a concession for the violation of social and economic rights in the interaction between affluent countries and poor countries in the past. In this regard, positive duty is less commendable according to this criterion. On the other hand, 
negative duty has higher degree of conformity to UDHR because it more powerfully emphasizes the sense of obligation to promote social and economic rights of all human beings. This is indicated in its view that foreign aid should be regarded as an obligation rather than charity. In short, negative duty is more commendable as an ethical guide for global justice.

The second parameter is the presence of good intention. This one is harder to investigate, but might still be done through analyzing the argument of the supporters of both negative and positive duty in global justice. Arguably, positive duty is more commendable than negative duty in terms of good intention. This is because positive duty predicates foreign aid on nothing except moral altruism. Meanwhile, negative duty regards foreign aid as a concession of the violation of the 'do no harm' principle in the past. It means that if there had not been violation of the principle in the past, there would not have been obligation for foreign aid. This shows that positive duty has a better intention than negative duty. Accordingly, positive duty is more commendable than negative duty.

The third parameter is the possibility to create a better world. According to this criterion, negative duty is ethically more commendable than the positive duty argument. This is because the former intends to restore justice by defending the rights of the powerless who have been the major victims of the negative impact of the expansion of globalization across time, while the latter intends to help the most unfortunate people without realizing their participation in harming others. Given this context, charity only creates a fiction of altruism. The fact that we know better now about how the current world is constructed, operates, and its future impact, should give no reason for affluent countries to limit their obligation only to positive duty.

Another problem with charity or positive duty is that they are still insufficient to stimulate states to contribute adequate funds to mitigate global injustice. For example, donor countries already made a commitment at the UN General Assembly in 1970 to allocate 0.7 percent of its Gross National Income for Official Development Assistance (ODA) by at least 1975 (in Pogge 2007, 11), but this target was far from achieved. UNDP statistics reveals that while the numbers of poor people increase over time, ODA declined throughout the prosperous 1990 from 0.33 percent in 1990 to 0.22 percent in 2000. This number then inclined again to reach back 0.33 percent in 2005, but only 10 percent was allocated for basic social services, covering education, primary health care, reproduction health and population programs, nutrition programs, safe water and sanitations, and institutional capacity for delivering these services. The increase of ODA is more driven by 'geostrategic concern,' such as humanitarian assistance to win the hearts and minds of Afghanistan and Iraq and also to give assistance to combat terrorism, rather than as a motive to address global problems. Even worse, as discovered by Pogge, the main USAID website once uploaded a statement saying that close to 80 percent of USAID programs were directly benefiting American firms. This agency also declares that the principal beneficiary of American foreign assistance programs has always been the US' (Pogge 2001a, 2) A more recent calculation also stated that only $19.8 \%$ of OECD's conventional aid has been allocated for the poorest nations in 2016. This shows that the motivation to help needy people is just superficial while the substance is mainly for self-interests. With the low political interests of affluent countries in the poorest countries, the most unfortunate people on earth receive the smallest proportion of ODA (Pogge 2007, 11). In this regard, negative duty is more responsive for the increasing demand for justice in current world politics because it enforces powerful states to reform the current system, to not only consider the interest of the powerful, but also the needs of the powerless. Even if this idea is not welcome in anarchical society, at least it will push the wider scope of morality in the current world. 
The discussion above demonstrates that the ethics of negative responsibility are more commendable than the ethics of positive responsibility because the former meet two of the three criteria of commendable ethics as proposed by Bertrand Russel (1961). While the latter only meets one criterion, that is still good intention. This means that we need the ethics of negative duty more than positive duty because it is consistent with our commitment to UDHR besides its transformative nature in creating a more just world.

However, it does not mean that the ethics of negative responsibility have greater practicability for the current context. There are at least three arguments that show this lack of practicability. Firstly, the principle of 'do no harm' is problematic. The notion can be subjective in a particular context because 'harm' to one society might be 'no harm' for others. It is also problematic as to whether this principle should be held normatively or based on its consequences, because many times we do the right thing with bad consequences (Pettit in Singer 1993, 230-240). For example, while food aid from the rich to poor countries is intended to help alleviate sufferings, this assistance could also generate unintended casualties when distributed in "countries that have experienced conflict in the recent past (Nunn and Qian 2014, 1662). This is why, in holding the principle of do no harm, we need to develop sensitivity to the context and the dynamics of people's aspirations. It is a moral capacity which is rare to find.

Secondly, it is too risky for international order if negative responsibility is only promoted partially. This distorts the balance between great powers because some actors would contribute more for a global justice agenda while others might exploit it. It will be costly comparatively if one donor contributes for altruism while the other donor contributes for its own national interests. Even Thomas Pogge admits that donor countries also face a competitive situation among themselves (Pogge in Crocker and Linden (eds.) 1998, 525. This is the issue of 'you first' in global justice which hampers the political will from the powerful to do global structural reform.

Thirdly, although ethically commendable, promoting negative duty is difficult because the source of evil is concealed by many historical narratives. For example, Jeffrey Herbst's research reveals that African states remain weak because of a 'physical geography' factor while Bernard Lewis argues that Islamic societies, including in Africa, were deteriorated because of 'internal development' issues in their communities rather than other causes (cited in Risse 2005, 13). Many versions of historical narratives challenge the effort to provide evidence of the importance of negative duty. The absence of institution which could rejoin these different versions of history putting the debate over global rights and responsibility keep on going. Rudiger Bittner categorizes this as 'a non-imputable state' because there are too many political economic decisions in one day and it is unclear which one creates harm and which does not (Bittner 2001, 31).

Thus, it will be a long way away for supporters of negative responsibility to be the main ethics in world politics. The acceptance of this principle relies on scholarly works which could reveal convincing connections between the history of globalisation and the world's poor. In the meantime, negative responsibility lives as integrity of only a few people who are convinced that the findings about structural causes of poverty are valid. This might not be enough to bring significant change, but at least it brings another inspiration for a better world we desire, a world where all human beings truly have equal respect and dignity.

\section{Conclusion}

Negative responsibility should be the ethical guidance of the current world politics. 
This principle promotes a responsibility of 'do no harm' which, most of the time, is neglected in the world where 'the might is right.' Although its practicality is still in question, this ethics of negative responsibility brings hope of reform in the way that international system operates. It will continue to broaden the space of morality in international relations and offer support for a better compromise between order and justice. In this regard, the border of responsibility in the discourse of global justice is continuing to be negotiated. I wish the world hunger could wait until affluent states accept this negative responsibility, because charity is definitely not enough to alleviate the poorest people's sufferings.

\section{References}

\section{Books and Chapter in Books}

Bull, Hedley, 1977. The Anarchical Society. Columbia University Press.

Cimadamore, Alberto D., et al., 2016. Poverty and the Milennium Development Goals: A Crittical Look Forward. London: Zed Books.

Crocker, David A., and Linden, Toby, 1998. Ethics of Consumption. Lanham, MD: Rowman and Littlefield.

McCarthy, Leo, 1998. Justice, the State and International Relations. London: MacMillan Press Ltd.

Morsink, Johannes, 1999. The Universal Declaration of Human Rights: Origins, Drafting and Intent. University of Pennsylvania Pers.

Pogge, Thomas Winfried Menko (ed.), 2007. Freedom from Poverty as Human Rights: Who Owes What to the Very Poor? USA: Oxford University Press.

Sen, Amartya, 2006. Identity and Violence: The Illusion of Destiny. New York: W.W. Norton \& Company.

Shiva, Vandana, 2000. Stolen Harvest: the Hijacking of the Global Food Supply. Boston MA: South End Press.

Singer, Peter, (ed.) A Companion to Ethics, Malden: Blackwell Publishing Ltd., 1993.

Stiglitz, Joseph E., 2002. Globalization and Its Discontents. New York: W.W. Norton and Company.

\section{Journal and Online Journal}

Beitz, Charles R., 2005. "Cosmopolitanism and Global Justice,” the Journal of Ethics, 9: $12-27$.

Bittner, Rudiger, 2001. "Morality and world Hunger," Metaphilosophy, 32 (1/2): 2533 .

Devetak, Richard, and Higott, Richard, 1999. “Justice Unbound? Globalization, States 
The Border of Responsibilities in Global Distribution of Aid: Ethical Issues and Challenges in Practices

and the Transformation of the Social Bond," International Affairs, 75 (3): 483-498.

Goodin, Robert E., 1988. "What is So Special about Our Fellow Countrymen," Ethics, 98 (4): 663-686.

Hickel, Jason, 2017. "Is Global Inequality Getting Better or Worse? A Critique of the World Bank's Convergence Narrative.” Third World Quarterly, 38 (10): 2208-2222.

Higgott, Richard, 2000. "Contested Globalization: the Changing context and Normative Challenges," Review of International Studies, 26: 131-153.

Holder, Cindy, 2012. "Global Justice Beyonf Distribution: Poverty and Natural Resources.” Public Affairs Quarterly, 26 (1): 33-34.

Kuper, Andrew, 2002b. "Facts, Theories, and Hard Choices," Ethics and International Affairs, 16 (2): 125-126.

Kuper, Andrew. 2002a. "More Than Charity: Cosmopolitan Alternatives to the 'Singer Solution," Ethics and International Affairs, 16 (2): 107-120.

Linklater, Andrew, 1999. "the Evolving Spheres of International Justice," International Affairs, 75 (3): 473-482.

Miller, David, 1988. “The Ethical Significance of Nationality.” Ethics, 98 (4): 647-662.

Nagel, Thomas, 2005. "The Problem of Global Justice." Philosophy and Public Affairs, 33 (2): 113-147.

O’Neill, Onora, 2000. "Bounded and Cosmopolitan Justice.” Review of International Studies, 26: 45-60.

O’Neill, Onora, 2001. “Agents of Justice.” Metaphilosophy, 32 (1/2): 180-195.

Pogge, Thomas, 2001a. "Introduction," Metaphilosophy, 32 (1/2): 1-5.

Pogge, Thomas, 2001b. "Priorities of Global Justice," Metaphilosophy, 32 (1/2): 6-24.

Pogge, Thomas, 2005. "World Poverty and Human Rights." Ethics and International Affairs, 19 (1): 1-7.

Pogge, Thomas, 2007. "Eradicating Systemic Poverty: Brief for a Global Resources Dividend.” International Journal of Human Rights, 6: 137-158.

Risse, Mathias, 2005. “Do We Owe the Global Poor Assistance or Rectification?” Ethics and International Affairs, 19 (1): 9-18.

Russell, Bertrand, 1961. "Science and Ethics." Religion and Science accessed through http://www.solstice.us/russell/science-ethics.html, accessed on 10 October 2008.

\section{Others}

Millennium Development Goals, 2008. Progress Chart: Country Progress within Region, http://mdgs.un.org/unsd/mdg/Resources/Static/Products/Progress2008, 
accessed on 2 October 2008.

OECD, 2017. Development Aid Rises Again in 2016 but Flows to Poorest Countries Dip, accessed through: http://www.oecd.org/dac/development-aid-rises-again-in2016-but-flows-to-poorest-countries-dip.htm on 18 September 2018.

The World Bank, 'The Costs of Attaining the Millennium Development Goals,' http:// www.worldbank.org/html/extdr/mdgassessment.pdf, accessed on 2 October 2008.

UN Millennium Project, 2005. Halving Hunger: It can be Done, http://www. unmillenniumproject.org/reports/tf hunger.htm, accessed on 2 October 2008.

Universal Declaration of Human Rights, adopted and proclaimed by General Assembly resolution 217 A (III) of 10 December 1948, http://www.un.org/Overview/rights. html, accessed on 10 October 2008. 
The Border of Responsibilities in Global Distribution of Aid: Ethical Issues and Challenges in Practices 